\title{
Heavy Oil Thermal Conversion and Refinement to the Green Petroleum: a Petrochemical Refinement Plant Using the Sustainable Formic Acid for the Process
}

\author{
Nima Norouzi ${ }^{1}$ (D), Saeed Talebi ${ }^{1, *(D)}$, Maryam Fabi ${ }^{1}$ (D), Hossein Khajehpour ${ }^{2}$ (D) \\ Faculty of Energy, Amirkabir University of Technology, Tehran, Iran \\ 2 Faculty of Energy, Sharif University of Technology, Tehran, Iran \\ * Correspondence: sa.talebi2015@gmaill.com;
}

Scopus Author ID 25650802200

Received: 19.03.2020; Revised: 25.04.2020; Accepted: 26.04.2020; Published: 2.05.2020

\begin{abstract}
In this study, heat oil conversion experiments using steam and formic acid as a hydrogen carrier be carried out in a batch reactor at $\mathrm{T}=380$ degrees of Celsius and $\mathrm{P}=165 \mathrm{bar}$. Material balance and product distribution were calculated after the process. Properties of crude oil before and after thermal conversion, including viscosity, API gravity, SARA measurement, and elemental analysis, were analyzed. It has been presented that the use of formic acid as a hydrogen carrier solvent reduces the formation of coke and gaseous products and enhances the performance of liquid products. Also, the viscosity of the refined oil decreased by $23.2 \%$ due to the addition of formic acid compared to the thermal conversion without hydrogen solvent. And also, a synthesis process is being implemented to provide the formic acid demand of the refining process sustainably. This process uses the carbon capture to contain $\mathrm{CO}_{2}$ for the direct green formic acid synthesis in the plant. Thus the oil produced by this process can be called green petroleum.
\end{abstract}

Keywords: formic acid; solar fuel; heavy oil; solar-petrochemical refining; green petroleum; heavy oil refinery; green petroleum refinery.

(C) 2020 by the authors. This article is an open access article distributed under the terms and conditions of the Creative Commons Attribution (CC BY) license (https://creativecommons.org/licenses/by/4.0/).

\section{Introduction}

Today climate change has become one of the main issues and concerns on the international scale. And these concerns led to a carbon emission reduction approach in all the industrial and residential sectors of the society. It has been found that fossil fuels contribute to a significant portion of greenhouse gas emissions (GHGE). Iran holds significant oil, gas, and power industries, which caused the country to become the home to the world's 7th most pollutant industry sector in 2017 [1]. However, more than $93 \%$ of the Iranian electricity is generated in the gas-fired power plants, and although the natural gas contains the least GHGE among the fossil fuel portfolio, still there is an excellent GHGE capture potential in the country which means more than 600 million tons of $\mathrm{CO}_{2}$ capture potential in the country [2].

Fig 1 shows that the GHGE in Iran rapidly increased in the past four decades. And the diagram in figure 2 illustrates that the Power sector and the industrial sector are playing the most crucial role in this rapid incremental trend [3]. The industrial sector, with $31.3 \%$, the power industry with $24.1 \%$, the residential area with $23.4 \%$, and Transportation with $21.2 \%$ are the most contaminant sectors of the society. The emission of residential and the transport sections because of their scattered nature is costly and difficult to be captured, but the power 
and industry can be easily used during the carbon capture process. Thus, the recoverable potential of carbon dioxide in Iran is a share of 55.4\% of the total carbon emissions [4].

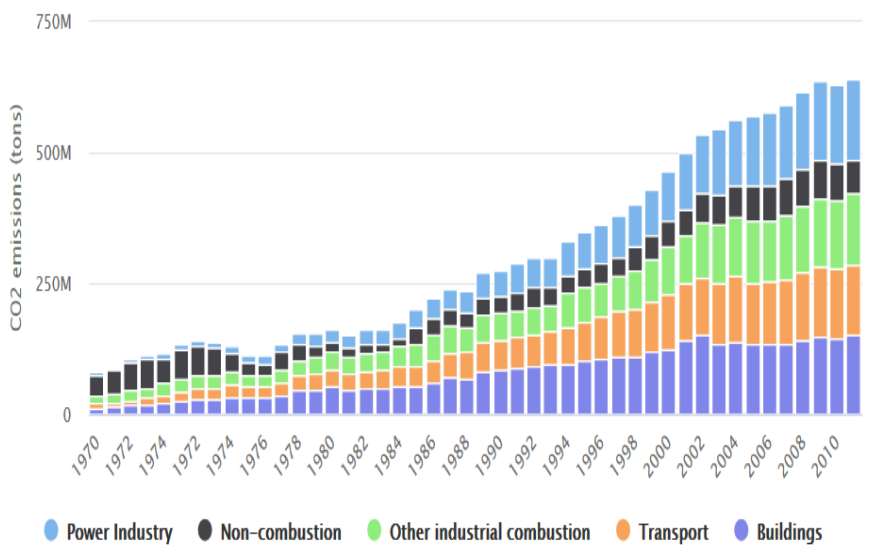

Figure 1. Iran $\mathrm{CO}_{2}$ emissions by year (tons); Conducted by the authors and Data source is worldometers.info.

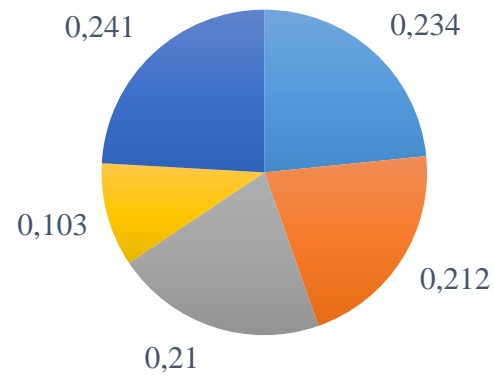

- Residential

- Transport

other industrial combustion

Non-combustion

- Power industry

Figure 2. $\mathrm{CO}_{2}$ emissions by sector in 2016; Conducted by the authors and Data source is worldometers.info

A study over the different carbon capture technologies is being implemented by Mattison et al. (2019). This research states that most of the standard carbon capture technologies (CCTs) consume a significant amount of energy during the process [5]. Adanez et al. (2013) introduce a novel chemical looping combustion method (CLC), which reduces energy consumption. Extensive researches on the CLC process is being conducted on gaseous fuels [6].

Cristian Cormos (2014) studied various carbon capture processes in the industries and power plants [6]. And in some of the cases, they have proposed that the Carbon dioxide + hydrogen to formic acid synthesis process be implemented on the unit.

Zeng et al. (2012) developed a kinetic and thermodynamic limitation based reactor for the CDU process. Zeng (2012) analyzed air, steam, and gas reactors. The process results shown that the CLC method has the potential to have efficiency more than $90 \% \mathrm{CO} 2$ for the capture process. In the Carbon capture process, post-combustion methods involve the treatment of the flue gas produced by the burning of the fuel [7].

The flue gas has consisted of nitrogen (about 78\%) along with water vapor and carbon dioxide, which their concentration depends on the fuel used during the combustion process. the other consisting of the flue gas such as mercury and heavy metals, Sulfur oxides and nitrogen 
oxides, particulate matters, and others are being removed in the stacks to meet the combustion standards [8]. The main problem and limitation of the carbon capture process is the low pressure of the flue gas in the stacks and post-combustion stages, and also the vast flow rate of the flue gas is the other issue of the capture process [9]. The Carbon concentration in the flue gas is $4 \%$ in the Bryton cycle, $15 \%$ for coal-fired periods, and $20-30 \%$ in the cement and steel production units [10].

In this paper, the chemical absorption in an aqueous solution of an amine-based organic, such as mono- or diethanolamine (MEA, DEA), is being used [11]. The efficiency of this process is $85-90 \%$, and its cost is highly defined by the amine Solvent. Alternative technologies for this technology with the high efficiency of the carbon recovery (90\%), not yet industrially used, are using the adsorption $\mathrm{CO}_{2}$ conversion, chemical looping, and membrane separation [12].

Merkel et al. using the MTR membrane Polaris (permeance $1000 \mathrm{GPU}, \mathrm{CO}_{2} / \mathrm{N}_{2}$ selectivity $\mathrm{a}=50$ ), and in their studies, they have found an optimal option (two-step counterflow/sweep membrane process).

Though the amine-based solution process costs about $60 \$ /$ ton, the later and alternative processes cast less than $20 \$ /$ ton, which presents a very prominent future for the membrane twostage process in the carbon capture industry [13]. And about the energy penalty, recent researches state that for capturing $90 \%$ of the $\mathrm{CO}_{2}$ from coal-fired system's flue gas (containing $12-14 \%$ of Carbon dioxide) is about $3.5 \%$ of the energy input of the system. However, the best commercial option increases this penalty to over $16 \%$. The most prominent semi-industrial technology reduces this penalty to $6 \%$ and overall $\mathrm{CO}_{2}$ capture cost to the $20 \$ /$ ton [14]. This cost per ton of $\mathrm{CO}_{2}$ capture is stated as the feasible point of the $\mathrm{CO}_{2}$ captured technologies. However, this viable point is highly dependent on the environmental policies implemented by the governments and international policymakers [15].

Conventional methods to produce hydrogen rely on the use of fossil fuels and electricity, which is not desirable because of its excellent carbon emission amount. Steam methane reforming (SMR) is one of the leading traditional hydrogen production methods [16]. Because although the process needs an external heat source but doesn't need pure oxygen [17].

Coal gasification (CG) is one of the traditional methods of hydrogen production and is more complicated compared to the SMR [18]. This 2 stage process causes the feedback costs to be decreased compared to the SMR while its capital cost is higher. In this method, the coal converted through steam/oxygen gasification or oxidation at a very high temperature and pressure to $\mathrm{CO}_{2}$-rich syngas, which is containing hydrogen contents enhanced during the watergas shift (WGS) reaction [19].

Another method is the plasma arc decomposition (PAD), in which the high-temperature pyrolysis of the methane produces solid carbon and pure hydrogen. The overall hydrogen production cost in the SMR is $750 \$ /$ ton and 920 \$/ton for the CG process [20].

One of the methods suitable for the large scale hydrogen production is the alkaline water electrolyzed (WE) [21]. The costs of this process are higher due to its catalyst used as an electrode for the required purification of the water before the electrolysis and due to the price of the electricity [22]. The commercially available systems produce hydrogen around 2000$3000 \$ /$ ton at a $0.05-0.06 \$ / \mathrm{kWh}$ electricity fee. In this case, the electricity can be easily provided by the solar photovoltaic systems (PV) to reduce the electricity generation emissions out of the table. There are many other alternative methods such as polymer electrolyte 
membranes (PEM), solid oxide electrolyzer (SOEC), and the carbon assisted water electrolysis (CAWE), which are not in the commercial status [23].

Carbon dioxide utilization (CDU) considers $\mathrm{CO}_{2}$ as raw material to synthesize carbonbased marketable products. Among them, formic acid $\left(\mathrm{HCOOH}\right.$, synthesized from $\left.\mathrm{CO}_{2}+\mathrm{H}_{2}\right)$ is considered as an efficient $\mathrm{H}_{2}$ carrier that improves $\mathrm{H}_{2}$ storage as a non-toxic, liquid, and easyto-store chemical [24]. This paper will be involved in the development of a reversible and fully renewable process of using captured Carbon dioxide and water Electrolyzed hydrogen in the conversion and synthesis of the FA using a Chem-thermal method. In turn, decomposition of formic acid $\left(\mathrm{HCOOH}=>\mathrm{CO}_{2}+\mathrm{H}_{2}\right)$ provides the needed $\mathrm{H}_{2}$ to power the fuel cell operation (electricity generation) or using the FA directly in the Heavy oil refining process. Thus, the method first transforms $\mathrm{H} 2$ into formic acid and then does the reverse reaction to restore $\mathrm{H}_{2}$, making the $\mathrm{CO}_{2}$ again available to be reused or directly used in the petrochemical refineries [25].

In recent decades, research has been conducted extensively on the development of new technologies for the production of heavy hydrocarbons, such as heavy and non-heavy oils, bitumen, petroleum sands [26]. This is due to a decrease in light oil production and an annual increase in the amount of heavy crude oil in recovery processes. Heavy oils contain large amounts of resin, asphaltene, and other heteroatomic compounds [27].

Many studies have been devoted to the use of unconventional methods that can ensure the production of lighter, so-called synthetic oils from heavy raw materials, which can be processed using existing designs without making significant changes to refinery processes. One of the promising ways to produce synthetic oil is to heat the heavy hydrocarbon raw materials in the presence of water as steam or critical or supercritical conditions [28]. It has been reported that the use of heated steam in the process of cyclic steam stimulation is provided for the recovery of thermally enhanced oils, including heavy oils and oil sands such as Athabasca oil sand and Orinoco heavy oil [29].

Further research by Li et al. suggests that heavy heat oil is injected into the oil tank when the steam is heated [30]. Also, Sung et al. Has proposed a new thermal conversion project for conventional heavy oils with excessively hot steam. The authors observed [31] that the reaction reaches a uniformity after a confirmation time and is not sensitive to the reaction time. Katritzky et al. It has been shown that water in the form of heated steam as a catalyst, shedding agent, and a suitable hydrogen donor solvent participates in the reaction of hydrocarbon compounds with heated steam [32].

Under these conditions, water has the properties of a non-polar donor protonating solvent. Also, the physical properties of water under these conditions, such as density, dielectric constant, hydrocarbon solubility, and ion separation constants, which can accelerate the rate of thermal conversion, have been significantly increased [33]. As a result, the efficiency of thermal processes can be increased to eliminate heavy oil raw materials and to obtain "synthetic" oils with low content of high molecular weight heteroatomic compounds and high content of small boiling fractions [34].

The major disadvantage for the thermal conversion of dense hydrocarbon sources in the presence of excess steam is the significant formation of coke and gaseous products [35], which results in the loss of the desired components of liquid products (synthetic oil). However, this can be solved by using some additives such as hydrogen-solubilizing solvents or any other useful material, which prevents the formation of coke and gas [36]. 
Also, the thermal conversion of heavy oils using hydrogen-solubilizing solvents with excessively hot steam results in an increase in the ratio of hydrogen and carbon, thereby transferring additional hydrogen from the hydrogen-solubilizing solvents, which in hydrogenation reactions ( Prevent recombinant formed radicals) [37]. It should be noted, many studies and work have shown that the use of additives such as hydrogen donor solvents or even various steam catalysts increases the efficiency of refining and converting heavy oils and reducing coke and gas formations [39].

Fan et al. Stated that by adding hydrogen donors and catalysts, coke and gas formation were reduced [40]. This technology has been successfully applied in this field with excellent results. For the super heavy oil (Shengli oil field, China), the viscosity reduction rate with the addition of a hydrogen donor was about $70 \%$ after the thermal catalytic refine [41].

In the Khuzestan region, Iran, there are many substantial and super-heavy oil fields developed using the Steam-Based Method for Advanced Oil Recovery (SAGD) [42]. Using hydrogenated solvents as an additive can help improve extraction efficiency and in situ refining. In this paper formic acid is used as hydrogen soluble with overheated steam, to reduce the formation of coke and gaseous products and to prevent recombinant reactions during the heating oil conversion process (the figure 3 shows that $38 \%$ of the oil reservoirs are heavy oil quality type and utilization of the solar-petrochemical plants and the green petroleum conversion helps to extract the remaining ultra-heavy oil reservoirs) [43].

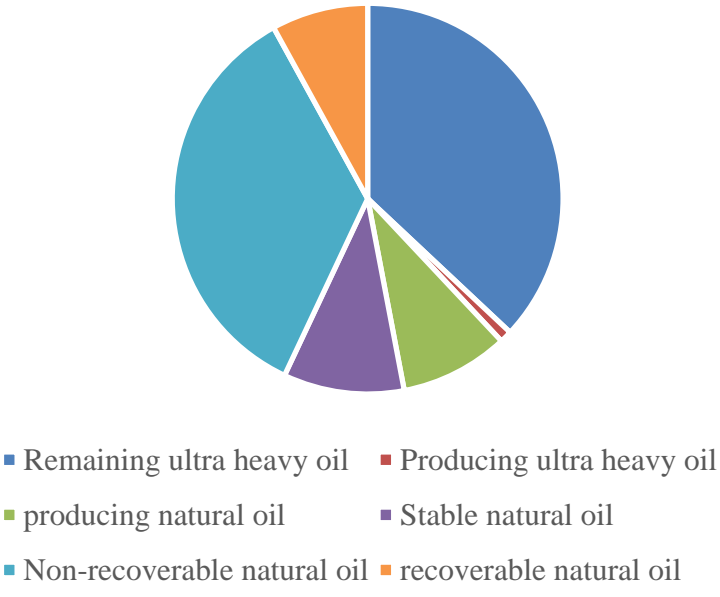

Figure 3. Shows the share of each oil quality in the oil reservoirs in Iran.

\section{Materials and Methods}

In this paper, an Electrochemical Carbon utilization plant is being implemented for the green Formic acid production. The electrochemical reduction process plant is illustrated in figure 4 [45].

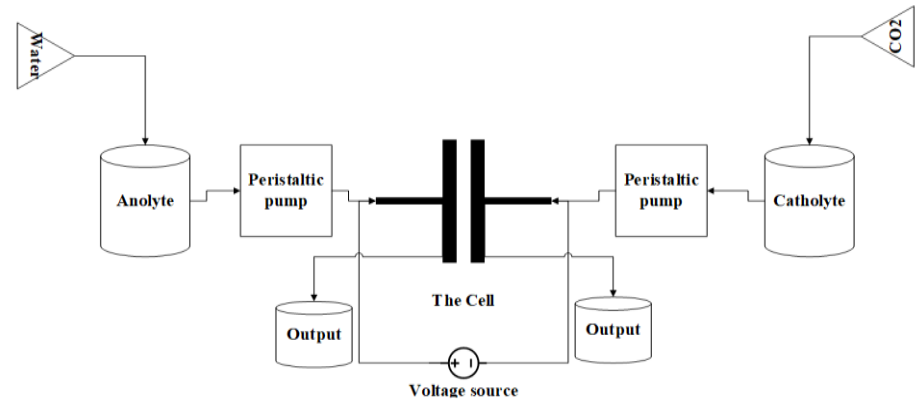

Figure. 4. Electrochemical reduction plant of formic acid. 
Figure 4 shows the electrochemical reduction plant for the FA production process, and in this plant, a set of membranes is

The chemical reaction of the process is being addressed in the equations below:

Cathodic reaction

$$
\begin{gathered}
\mathrm{CO}_{2}+\mathrm{H}_{2} \mathrm{O}+2 e^{-} \rightarrow \mathrm{HCOO}^{-}+\mathrm{OH}^{-} \\
2 \mathrm{H}_{2} \mathrm{O}+2 e^{-} \rightarrow \mathrm{H}_{2}+2 \mathrm{OH}^{-}(2)
\end{gathered}
$$

Anodic reaction

$$
\mathrm{H}_{2} \mathrm{O} \rightarrow 2 \mathrm{H}++2 e^{-}+\frac{1}{2} \mathrm{O}_{2}(3)
$$

Overall reaction

$$
\mathrm{CO}_{2}+2 \mathrm{H}_{2} \mathrm{O} \rightarrow \mathrm{HCOOH}+\mathrm{O}_{2}+\mathrm{H}_{2}(4)
$$

The energy needed in the carbon capture and carbon dioxide utilization processes is generated by solar energy using photovoltaic or solar concentration technologies. This fact indicates that the Formic acid is fully supported by renewable energy [50]. The overall utility is being designed and illustrated in figure 5 below [51].

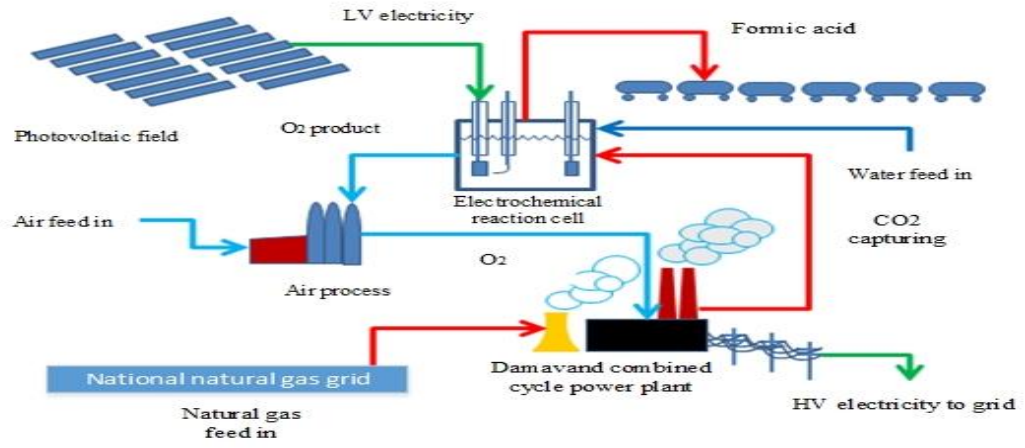

Figure. 5. The solar Formic acid production plant.

This paper uses the heavy oil of the Khuzestan region, Iran, for the case study. The main specifications of the oil are shown in Table 1 [53].

Table. 1. Characteristics of the studied oil.

\begin{tabular}{l|l|l|l}
\hline Parameter & \multicolumn{1}{c}{ Value } & \multicolumn{1}{c}{ Parameter } & \multicolumn{1}{c}{ Value } \\
API Gravity & 14.1 & Elemental analysis (wt. \%) \\
\hline Viscosity, @ 25C & 2073 & Carbon & 83.68 \\
\hline Saturates, \% mass. & 28.79 & Hydrocarbon & 11.44 \\
\hline Aromatics, \% mass. & 44.32 & Sulfur & 4.52 \\
\hline Resin, \%mass. & 20.98 & Nitrogen & 0.36 \\
\hline Asphaltenes, \%mass. & 5.91 & &
\end{tabular}

Refining experiments were carried out in a $350 \mathrm{ml}$ stainless steel Parr reactor equipped with a heating device and a temperature controller [54]. In a typical experiment, the reactor was loaded with crude oil and water at a weight ratio of 2: 1, respectively. The reactor was heated to $5^{\circ} \mathrm{C} / \mathrm{min}$ to $380^{\circ} \mathrm{C}$ and with a final pressure of approximately 164 bars for 6 hours (initial 2 bar pressure of N2). Heat conversion experiments were performed using a steam solvent and a hydrogen donor ( $2 \%$ mas. Formic acid) under the same conditions without a hydrogen solvent experiment [55].

Physical-chemical properties such as viscosity, API gravity, and SARA analysis of the oil before and after the thermal process in the presence and absence of formic acid were 
investigated [56]. The viscosity and weight of API oil were measured using an SVM-3000 Stabinger viscometer [57]. The initial composition of the oil was determined before and after conversion by a Perkin Elmer 2400 Series II analyzer. SARA analysis was performed according to ASTM D 4124 [58].

\section{Results and Discussion}

\subsection{Formic acid production.}

The results of the implementation of the Carbon utilization process on a solarpetrochemical plant which is illustrated in table 2, shows that the anodic material and anolyte of the electrochemical reduction reaction importance in the overall result of the process and because of the importance the best possible option for the green petroleum production is being implemented and used to design the formic acid production [59].

\subsection{Heavy oil to green petroleum conversion.}

The mass equilibrium (Table 3) of the three kinds of products, namely liquids, gas, and coke, was calculated for the two experiments as \%mass. of feed oil in the reactor using Eq. (1) and (2) [60]:

$$
\begin{aligned}
\text { Yield }(w t . \%) & =\frac{W i}{W F} \times 100 \\
\text { Yield of gas }(w t . \%) & =\frac{W F-W A}{W F} \times 100(6)
\end{aligned}
$$

Table. 2. The implementation of the scenarios on the solar-petrochemical plant.

\begin{tabular}{l|l|l}
\multicolumn{1}{c}{ parameter } & \multicolumn{1}{c}{ unit } & \multicolumn{1}{c}{ IrO $\mathbf{2}_{2}$ anolyte } \\
Formic acid production & $\mathrm{Kg} / \mathrm{s}$ & 79.70 \\
\hline carbon capture & $\mathrm{Kg} / \mathrm{s}$ & 75.20 \\
\hline power penalty & $\mathrm{kWh} / \mathrm{s}$ & 376.38 \\
\hline Total efficiency & $\%$ & 0.44 \\
\hline investment cost & $\mathrm{M} \$$ & 7.2 \\
\hline Exergy rate cost & $\$ / \mathrm{kWh}$ exergy & 0.21 \\
\hline Flow stream cost & $\$ / \mathrm{s}^{*}\left(10^{-3}\right)$ & 22.80
\end{tabular}

Table. 3. Material balance for thermal conversion of crude oil at $380{ }^{\circ} \mathrm{C}$.

\begin{tabular}{l|c|c|c|c} 
Scenarios & Temperature, ${ }^{\circ} \mathbf{C}$ & Liquid yield (wt, \%) & Coke yield (wt, \%) & Gas yields (wt, \%) \\
\hline Scenario 1 & 380 & 74.3 & 16.81 & 7.41 \\
\hline Scenario 2 & 380 & 81.2 & 13.94 & 5.98
\end{tabular}

\begin{tabular}{|c|c|c|c|c|c|c|}
\hline \multirow[t]{2}{*}{ Reaction system } & \multirow{2}{*}{$\begin{array}{l}\text { viscosity at } \\
25^{\circ} \mathrm{C}, \mathrm{mPa} \cdot \mathrm{s}\end{array}$} & \multirow{2}{*}{$\begin{array}{l}\text { OAPI, } \\
\text { gravity }\end{array}$} & \multicolumn{4}{|c|}{ mass content, $\%$} \\
\hline & & & Saturates & Aromatics & Resins & Asphaltenes \\
\hline Base & 2073 & 14.1 & 28.79 & 44.32 & 20.98 & 5.91 \\
\hline Scenario 1 & 16.21 & 21.5 & 55.2 & 29.8 & 12.5 & 2.5 \\
\hline Scenario 2 & 11.96 & 22.98 & 58 & 31 & 9.7 & 1.3 \\
\hline
\end{tabular}

Table. 4. Viscosity, API gravity and SARA composition of oil before and after thermal conversion.

Where the weight is the weight of the components $\mathrm{i}$ and wf, the weight of feed oil (heavy oil loaded in the reactor), and the WA is the amount of coke and liquid phase weight in the autoclave after testing. Two scenarios in this paper have been studied. The first is a classic thermal conversion of the heavy oil, and the other is the formic acid thermal conversion [61].

From Table 3, it can be shown that due to the polymerization and high density of high molecular weight components, the high performance of coke and gas after heat updraft with 
steam is indicated. Conversely, adding formic acid to the reaction system reduces the performance of coke and gases and increases the liquid phase content.

The results of studies on crude oil properties (viscosity, API gravity, and SARA analysis) are presented before and after refining in steam-heated conditions in Table 4.

From Table 2, we can observe an increase in the content of the saturation fraction and a decrease in the amount of resin due to the thermal conversion of heavy oil with and without formic acid as a hydrogen carrier solvent. However, the degree of conversion is higher in the presence of formic acid. The use of hydrogen donor contributes to the degradation of high molecular weight components (resin and Asphaltenes) of heavy oil [10, 11]. Compared to the initial oil, the saturation content is significantly increased, and the amount of resin and Asphaltenes is significantly increased. The same conditions are heated by steam and reduced by formic acid. These changes are reflected by increasing API gravity from 21.5 to 22.98 by adding hydrogen donor solvent and reducing the viscosity from 2073 to 16.21 without formic acid and 11.96 with it.

As shown in Table 5, a preliminary analysis of oil before and after heat conversion, we can observe a significant decrease in heteroatoms, especially the sulfur content from 4.52 for primary oil to 2.96 with overheated steam and 2.77 . Heated by steam and formic acid. At the same time, we can reduce the percentage of carbon and hydrogen due to their conversion to coke and gas after the polymerization and condensation process. It should be noted that the addition of formic acid as a hydrogen donor solvent increases the percentage of hydrogen compared to the refine without formic acid.

Table. 5. Elemental analysis of crude oil before and after thermal conversion.

\begin{tabular}{l|c|c|c|c}
\multirow{2}{*}{ Base } & \multicolumn{4}{c}{ Content, wt.\% } \\
\hline Scenario 1 & 83.68 & H & N & S \\
\hline Scenario 2 & 83.65 & 83.68 & 83.68 & 83.68 \\
\hline
\end{tabular}

Heat conversion of heavy crude oil using overheated steam combined with formic acid as a hydrogen solvent gave promising results [62]. The content of high molecular weight heteroatomic materials such as resin and Asphaltenes has been reduced, unlike thermal treatment using steam-only heating [63].

The viscosity of the heavy oil improved with the addition of formic acid, compared to the thermal conversion without the donor hydrogen solvent (viscosity reduction was 23.2) [64]. Also, the use of formic acid as a hydrogen soluble reduces the yield of coke and gaseous products, increasing the number of liquid products (refined oil).

Also, a decrease in sulfur content was observed due to the addition of formic acid as a proton donor for the thermal conversion process [65].

\section{Conclusions}

Global warming caused by greenhouse gas accumulation in the atmosphere is one of the major threats to the environment [66]. Via concerns spread, increase research to convert carbon dioxide to the valuable ingredient. In the number of scientific agreements in recent decades, for capturing, fixation, and technologies to drive carbon dioxide content [67].

Carbon dioxide as the most important greenhouse gases has adverse effects on the environment Due to the reduction of fossil fuels, carbon dioxide consumption also needs to be formulated and applied [68]. New publications of $\mathrm{CO}_{2}$ reduction catalysts show remarkable 
action to improve catalyst activity [69]. Such endeavors get a profit from basic mechanistic studies and simulation of classes of the catalytic material. Another opportunity for activity improvement is fin- tuning electrolyte composition for a specified catalyst [55].

The best opportunity for enhancing performance is optimizing electrode structure and composition of the subatomic layer than similar electrodes in the same cell, and more try should focus on the physical properties of gas diffusion [56]. These items improve the performance of the system and convert $\mathrm{CO}_{2}$ reduction to valuable chemical materials [43].

Recent publications of $\mathrm{CO}_{2}$ reduction catalysts show remarkable action to improve catalyst activity. Such endeavors get a profit from basic mechanistic studies and simulation of classes of the catalytic material [66]. Another opportunity for activity improvement is fintuning electrolyte composition for a specified catalyst [62].

The best opportunity for enhancing performance is optimizing electrode structure and composition of the subatomic layer than similar electrodes in the same cell, and more try should focus on the physical properties of gas diffusion [68]. These items improve the performance of the system and convert $\mathrm{CO}_{2}$ reduction to valuable chemical materials[21].

Based on the formic acid solar fuel studies, it is obvious that the CDU processes can be implemented and is a feasible option for the carbon abatement processes [11, 69]. The utilization of this method means lesser fuel consumption and negative net emission, which helps to manage the emissions throughout the plant [23]. But this research indicates that there is a need for R\&D study over the electrolyzers, which helps this industry become more mature and economically feasible [15].

Although the CDU-photovoltaic hybrid is feasible, it has very high risk right now and needs more uncertainty and risk study over the matter [55]. But the combination of the CDU processes with the renewable energy systems highly reduces the risk of the investment [30]. And the R and D studies and the developments support the process to become a more feasible, thus lesser risk in the investment $[31,70]$.

\section{Funding}

This research received no external funding.

\section{Acknowledgments}

We, the authors in this section, acknowledge the scientific supports of the Amirkabir university of technology.

\section{Conflicts of Interest}

The authors declare no conflict of interest.

\section{References}

1. Norouzi, N.; Fani, M.; Karami Ziarani, Z. The fall of oil Age: A scenario planning approach over the last peak oil of human history by 2040. Journal of Petroleum Science and Engineering 2020, 188, https://doi.org/10.1016/j.petrol.2019.106827.

2. Iran's $\mathrm{CO} 2$ emission by year and sector. Available: worldometers.info

3. Pérez-Fortes, M.; Tzimas, E. Techno-Economic and Environmental Evaluation of CO2 Utilization for Fuel Production-Synthesis of Methanol and Formic Acid. Publications Office of the European Union: Luxembourg, 2016. 
4. Pérez-Fortes, M.; Schöneberger, J.C.; Boulamanti, A.; Harrison, G.; Tzimas, E. Formic acid synthesis using $\mathrm{CO} 2$ as raw material: Techno-economic and environmental evaluation and market potential. International Journal of Hydrogen Energy 2016, 41, 16444-16462, https://doi.org/10.1016/j.ijhydene.2016.05.199.

5. Gayán, P.; Cabello, A.; García-Labiano, F.; Abad, A.; de Diego, L.F.; Adánez, J. Performance of a low Ni content oxygen carrier for fuel gas combustion in a continuous CLC unit using a CaO/Al2O3 system as support. International Journal of Greenhouse Gas Control 2013, 14, 209-219, https://doi.org/10.1016/j.ijggc.2013.01.025.

6. Mattison, T.; Hildor, F.; Li, Y.; Linderholm, C. Negative emissions of carbon dioxide through chemicallooping combustion (CLC) and gasification (CLG) using oxygen carriers based on manganese and iron. Mitigation and Adaptation Strategies for Global Change 2019, https://doi.org/10.1007/s11027-019-09860$\mathrm{X}$.

7. Cormos, C.C.; Petrescu, L.; Cormos, A.M. Assessment of Hydrogen Production Systems based on Natural Gas Conversion with Carbon Capture and Storage. In: Computer Aided Chemical Engineering. Editor(s): Klemeš, J.J.; Varbanov, P.S.; Liew, P.Y. Elsevier, Volume 33, 2014, pp. 1081-1086, https://doi.org/10.1016/B978-0-444-63455-9.50015-5.

8. Bobicki, E.R.; Liu, Q.; Xu, Z.; Zeng, H. Carbon capture and storage using alkaline industrial wastes. Progress in Energy and Combustion Science 2012, 38, 302-320, https://doi.org/10.1016/j.pecs.2011.11.002.

9. Van Eerten-Jansen, M.C.; Veldhoen, M.B.; Plugge, C.M.; Stams, A.J.; Buisman, C.G.; Ter Heijne, A. Microbial community analysis of a methane producing bio cathode in a bio electrochemical system. Archaea 2013.

10. Pearlman, H.; Chen, C.H. Syngas production by thermochemical conversion of $\mathrm{CO} 2$ and $\mathrm{H} 2 \mathrm{O}$ mixtures using a high-temperature heat pipe based reactor. In: SPIE Solar Energy+. Technology International Society for Optics and Photonics 2012.

11. Li, K.; An, X.; Park, K.H.; Khraisheh, M.; Tang, J. A critical review of CO2 photoconversion: Catalysts and reactors. Catalysis Today 2014, 224, 3-12, https://doi.org/10.1016/j.cattod.2013.12.006.

12. Scibioh, M.A.; Viswanathan, B. Electrochemical reduction of carbon dioxide: a status report. Proc Indian Natn Sci Acad. 2004.

13. Adachi, K.; Ohta, K.; Mizuno, T. Photocatalytic reduction of carbon dioxide to hydrocarbon using copperloaded titanium dioxide. Solar Energy 1994, 53, 187-190, https://doi.org/10.1016/0038-092X(94)90480-4.

14. Norouzi, N. An overview on Water, Energy \& Environment by 2030 In the term of global scenarios. The 5th International Conference on Technology and Energy Management With the approach of energy, water and environment nexus, Tehran, Iran 2018.

15. Norouzi, N. Solar energy, rural stable development \& subsistence”, ICTGE-17, Tehran, Iran, 2017.

16. Gallego-Álvarez, I.; Segura, L.; Martínez-Ferrero, J. Carbon emission reduction: the impact on the financial and operational performance of international companies. Journal of Cleaner Production 2015, 103, 149159, https://doi.org/10.1016/j.jclepro.2014.08.047.

17. Tang, D.; Dou, Y.; Yin, H.; Mao, X.; Xiao, W.; Wang, D. The capacitive performances of carbon obtained from the electrolysis of $\mathrm{CO} 2$ in molten carbonates: Effects of electrolysis voltage and temperature. Journal of Energy Chemistry 2019, https://doi.org/10.1016/j.jechem.2019.11.006.

18. Xie, H.; Wang, J.; Ithisuphalap, K.; Wu, G.; Li, Q. Recent advances in Cu-based nanocomposite photocatalysts for CO2 conversion to solar fuels. Journal of Energy Chemistry 2017, 26, 1039-1049, https://doi.org/10.1016/j.jechem.2017.10.025.

19. Passalacqua, R.; Perathoner, S.; Centi, G. Semiconductor, molecular and hybrid systems for photoelectrochemical solar fuel production. Journal of Energy Chemistry 2017, 26, 219-240, https://doi.org/10.1016/j.jechem.2017.03.004.

20. Fu, M.; Xu, H.; Ma, H.; Li, X. Theoretical assessment of hydrogen production and multicycle energy conversion via solar thermochemical cycle based on nonvolatile SnO2. Journal of Energy Chemistry 2019, 38, 177-184, https://doi.org/10.1016/j.jechem.2019.03.035.

21. Chuayboon, S.; Abanades, S.; Rodat, S. Solar chemical looping reforming of methane combined with isothermal $\mathrm{H} 2 \mathrm{O} / \mathrm{CO} 2$ splitting using ceria oxygen carrier for syngas production. Journal of Energy Chemistry 2020, 41, 60-72, https://doi.org/10.1016/j.jechem.2019.05.004.

22. Han, S.; Chen, Y.; Abanades, S.; Zhang, Z. Improving photoreduction of CO2 with water to CH4 in a novel concentrated solar reactor. Journal of Energy Chemistry 2017, 26, 743-749, https://doi.org/10.1016/j.jechem.2017.03.006. 
23. Zhang, X.-F.; Liu, C.; Wu, J.; Xu, B. Tetrabenzotriazacorrole and its derivatives as undoped hole transporting materials for perovskite solar cells: Synthesis, device fabrication, and device performance. Journal of Energy Chemistry 2020, 43, 139-147, https://doi.org/10.1016/j.jechem.2019.08.012.

24. Genovese, C.; Ampelli, C.; Perathoner, S.; Centi, G. Electrocatalytic conversion of CO2 to liquid fuels using nanocarbon-based electrodes. Journal of Energy Chemistry 2013, 22, 202-213, https://doi.org/10.1016/S2095-4956(13)60026-1.

25. Iqbal, M.Z.; Rehman, A.-U.; Siddique, S. Prospects and challenges of graphene based fuel cells. Journal of Energy Chemistry 2019, 39, 217-234, https://doi.org/10.1016/j.jechem.2019.02.009.

26. Wang, X.; Tang, R.; Wu, C.; Zhu, C.; Chen, T. Development of antimony sulfide-selenide Sb2(S, Se)3based solar cells. Journal of Energy Chemistry 2018, 27, 713-721, https://doi.org/10.1016/j.jechem.2017.09.031.

27. Wang, J.; Yuan, Y.; Zhu, H.; Cai, T.; Fang, Y.; Chen, O. Three-dimensional macroporous photonic crystal enhanced photon collection for quantum dot-based luminescent solar concentrator. Nano Energy 2020, 67, https://doi.org/10.1016/j.nanoen.2019.104217.

28. Khataee, A.; Azevedo, J.; Dias, P.; Ivanou, D.; Dražević, E.; Bentien, A.; Mendes, A. Integrated design of hematite and dye-sensitized solar cell for unbiased solar charging of an organic-inorganic redox flow battery. Nano Energy 2019, 62, 832-843, https://doi.org/10.1016/j.nanoen.2019.06.001.

29. Fu, Q.; Xiao, S.; Li, Z.; Li, Y.; Kobayashi, H.; Li, J.; Yang, Y.; Liao, Q.; Zhu, X.; He, X., et al. Hybrid solarto-methane conversion system with a Faradaic efficiency of up to 96\%. Nano Energy 2018, 53, 232-239, https://doi.org/10.1016/j.nanoen.2018.08.051.

30. Lin, R.; Lei, H.; Ruan, D.; Jiang, K.; Yu, X.; Wang, Z.; Mai, W.; Yan, H. Solar-powered overall water splitting system combing metal-organic frameworks derived bimetallic nanohybrids based electrocatalysts and one organic solar cell. Nano Energy 2019, 56, 82-91, https://doi.org/10.1016/j.nanoen.2018.10.058.

31. Lei, B.; Li, G.R.; Chen, P.; Gao, X.P. A solar rechargeable battery based on hydrogen storage mechanism in dual-phase electrolyte. Nano Energy 2017, 38, 257-262, https://doi.org/10.1016/j.nanoen.2017.06.001.

32. Li, Y.; Lin, C.; Zhou, D.; An, Y.; Li, D.; Chi, C.; Huang, H.; Yang, S.; Tso, C.Y.; Chao, C.Y.H.; Huang, B. Scalable all-ceramic nanofilms as highly efficient and thermally stable selective solar absorbers. Nano Energy 2019, 64, https://doi.org/10.1016/j.nanoen.2019.103947.

33. Ma, W.; Li, X.; Lu, H.; Zhang, M.; Yang, X.; Zhang, T.; Wu, L.; Cao, G.; Song, W. A flexible self-charged power panel for harvesting and storing solar and mechanical energy. Nano Energy 2019, 65, https://doi.org/10.1016/j.nanoen.2019.104082.

34. Jin, B.; Cho, Y.; Zhang, Y.; Chun, D.H.; Li, P.; Zhang, K.; Lee, K.-S.; Park, J.H. A “surface patching” strategy to achieve highly efficient solar water oxidation beyond surface passivation effect. Nano Energy 2019, 66, https://doi.org/10.1016/j.nanoen.2019.104110.

35. Xu, B.; Tian, L.; Etman, A.S.; Sun, J.; Tian, H. Solution-processed nanoporous NiO-dye-ZnO photocathodes: Toward efficient and stable solid-state p-type dye-sensitized solar cells and dye-sensitized photoelectrosynthesis cells. Nano Energy 2019, 55, 59-64, https://doi.org/10.1016/j.nanoen.2018.10.054.

36. Nandakumar, D.K.; Vaghasiya, J.V.; Yang, L.; Zhang, Y.; Tan, S.C. A solar cell that breathes in moisture for energy generation. Nano Energy 2020, 68, https://doi.org/10.1016/j.nanoen.2019.104263.

37. Lashgari, M.; Zeinalkhani, P. Ammonia photosynthesis under ambient conditions using an efficient nanostructured FeS2/CNT solar-energy-material with water feedstock and nitrogen gas. Nano Energy 2018, 48, 361-368, https://doi.org/10.1016/j.nanoen.2018.03.079.

38. Agosti, A.; Nakibli, Y.; Amirav, L.; Bergamini, G. Photosynthetic H2 generation and organic transformations with CdSe@CdS-Pt nanorods for highly efficient solar-to-chemical energy conversion. Nano Energy 2020, 70, https://doi.org/10.1016/j.nanoen.2020.104510.

39. Wu, Q.; Guo, J.; Sun, R.; Guo, J.; Jia, S.; Li, Y.; Wang, J.; Min, J. Slot-die printed non-fullerene organic solar cells with the highest efficiency of $12.9 \%$ for low-cost PV-driven water splitting. Nano Energy 2019 , 61, 559-566, https://doi.org/10.1016/j.nanoen.2019.04.091.

40. Wang, H.; Qian, F.; Li, Y. Solar-assisted microbial fuel cells for bioelectricity and chemical fuel generation. Nano Energy 2014, 8, 264-273, https://doi.org/10.1016/j.nanoen.2014.06.004.

41. Zhu, B.; Huang, Y.; Fan, L.; Ma, Y.; Wang, B.; Xia, C.; Afzal, M.; Zhang, B.; Dong, W.; Wang, H., et al. Novel fuel cell with nanocomposite functional layer designed by perovskite solar cell principle. Nano Energy 2016, 19, 156-164, https://doi.org/10.1016/j.nanoen.2015.11.015.

42. Zhou, H.; Li, P.; Liu, J.; Chen, Z.; Liu, L.; Dontsova, D.; Yan, R.; Fan, T.; Zhang, D.; Ye, J. Biomimetic polymeric semiconductor based hybrid nanosystems for artificial photosynthesis towards solar fuels 
generation via $\mathrm{CO} 2$ reduction. Nano Energy 2016, 25, 128-135, https://doi.org/10.1016/j.nanoen.2016.04.049.

43. Kim, S.; Han, K.; Kim, W.; Jeon, S.; Yong, K. An autodriven, solar fuel collection for a highly compact, biomimetic-modified artificial leaf without membrane. Nano Energy 2019, 58, 484-491, https://doi.org/10.1016/j.nanoen.2019.01.067.

44. Waidhas, F.; Jevric, M.; Fromm, L.; Bertram, M.; Görling, A.; Moth-Poulsen, K.; Brummel, O.; Libuda, J. Electrochemically controlled energy storage in a norbornadiene-based solar fuel with $99 \%$ reversibility. Nano Energy 2019, 63, https://doi.org/10.1016/j.nanoen.2019.103872.

45. Gao, X.; Liu, G.; Zhu, Y.; Kreider, P.; Bayon, A.; Gengenbach, T.; Lu, T.; Liu, Y.; Hinkley, J.; Lipiński, W.; Tricoli, A. Earth-abundant transition metal oxides with extraordinary reversible oxygen exchange capacity for efficient thermochemical synthesis of solar fuels. Nano Energy 2018, 50, 347-358, https://doi.org/10.1016/j.nanoen.2018.05.045.

46. Zhu, Y.; Gong, L.; Zhang, D.; Wang, X.; Zhang, J.; Zhang, L.; Dai, L.; Xia, Z. Catalytic origin and universal descriptors of heteroatom-doped photocatalysts for solar fuel production. Nano Energy 2019, 63, https://doi.org/10.1016/j.nanoen.2019.06.015.

47. Liang, J.; Zhu, G.; Wang, C.; Zhao, P.; Wang, Y.; Hu, Y.; Ma, L.; Tie, Z.; Liu, J.; Jin, Z. An all-inorganic perovskite solar capacitor for efficient and stable spontaneous photocharging. Nano Energy 2018, 52, 239245, https://doi.org/10.1016/j.nanoen.2018.07.060.

48. Ouedraogo, N.A.N.; Chen, Y.; Xiao, Y.Y.; Meng, Q.; Han, C.B.; Yan, H.; Zhang, Y. Stability of allinorganic perovskite solar cells. Nano Energy 2020, 67, https://doi.org/10.1016/j.nanoen.2019.104249.

49. Ni, F.; Xiao, P.; Qiu, N.; Zhang, C.; Liang, Y.; Gu, J.; Xia, J.; Zeng, Z.; Wang, L.; Xue, Q., et al. Collective behaviors mediated multifunctional black sand aggregate towards environmentally adaptive solar-to-thermal purified water harvesting. Nano Energy 2020, 68, https://doi.org/10.1016/j.nanoen.2019.104311.

50. Lou, Z.; Yuan, D.; Zhang, F.; Wang, Y.; Li, Y.; Zhu, L. Fe3Si assisted Co3O4 nanorods: A case study of photothermal catalytic CO oxidation under ambient solar irradiation. Nano Energy 2019, 62, 653-659, https://doi.org/10.1016/j.nanoen.2019.05.080.

51. Wang, H.; Zhao, Y.; Wang, Z.; Liu, Y.; Zhao, Z.; Xu, G.; Han, T.H.; Lee, J.W.; Chen, C.; Bao, D.; Huang, Y.; Duan, Y.; Yang, Y. Hermetic seal for perovskite solar cells: An improved plasma enhanced atomic layer deposition encapsulation. Nano Energy 2020, 69, https://doi.org/10.1016/j.nanoen.2019.104375.

52. Wu, F.; Lin, H.; Yang, Z.; Liao, M.; Wang, Z.; Li, Z.; Gao, P.; Ye, J.; Shen, W. Suppression of surface and Auger recombination by formation and control of radial junction in silicon microwire solar cells. Nano Energy 2019, 58, 817-824, https://doi.org/10.1016/j.nanoen.2019.02.021.

53. Ramadan, M.; Khaled, M.; Ramadan, H.S.; Becherif, M. Modeling and sizing of combined fuel cell-thermal solar system for energy generation. International Journal of Hydrogen Energy 2016, 41, 19929-19935, https://doi.org/10.1016/j.ijhydene.2016.08.222.

54. Mehrjerdi, H. Off-grid solar powered charging station for electric and hydrogen vehicles including fuel cell and hydrogen storage. International Journal of Hydrogen Energy 2019, 44, 11574-11583, https://doi.org/10.1016/j.ijhydene.2019.03.158.

55. Haddad, A.; Ramadan, M.; Khaled, M.; Ramadan, H.S.; Becherif, M. Triple hybrid system coupling fuel cell with wind turbine and thermal solar system. International Journal of Hydrogen Energy 2020, 45, 1148411491, https://doi.org/10.1016/j.ijhydene.2019.05.143.

56. Kong, H.; Kong, X.; Wang, H.; Wang, J. A strategy for optimizing efficiencies of solar thermochemical fuel production based on nonstoichiometric oxides. International Journal of Hydrogen Energy 2019, 44, 1958519594, https://doi.org/10.1016/j.ijhydene.2019.05.197.

57. Kovač, A.; Paranos, M. Design of a solar hydrogen refuelling station following the development of the first Croatian fuel cell powered bicycle to boost hydrogen urban mobility. International Journal of Hydrogen Energy 2019, 44, 10014-10022, https://doi.org/10.1016/j.ijhydene.2018.11.204.

58. Blal, M.; Belasri, A.; Benatillah, A.; Hamouda, M.; Lachtar, S.; Sahouane, N.; Laribi, S.; Mostefaoui, M. Assessment of solar and wind energy as motive for potential hydrogen production of Algeria country; development a methodology for uses hydrogen-based fuel cells. International Journal of Hydrogen Energy 2018, 43, 9192-9210, https://doi.org/10.1016/j.ijhydene.2018.03.200.

59. Fani, M.; Norouzi, Nima, Using Social and Economic Indicators for Modeling, Sensitivity Analysis and Forecasting the Gasoline Demand in the Transportation Sector An ANN Approach in case study for Tehran metropolis. Iranian Journal of Energy International energy agency 2019. 
60. Brege, A.; Méreau, R.; McGehee, K.; Grignard, B.; Detrembleur, C.; Jerome, C.; Tassaing, T. The coupling of $\mathrm{CO} 2$ with diols promoted by organic dual systems: Towards products divergence via benchmarking of the performance metrics. Journal of CO2 Utilization 2020, 38, 88-98, https://doi.org/10.1016/j.jcou.2020.01.003.

61. O'Brien, M. An automated colorimetric inline titration of $\mathrm{CO} 2$ concentrations in solvent flow streams using a Teflon AF-2400 tube-in-tube device. Journal of CO2 Utilization 2017, 21, 580-588, https://doi.org/10.1016/j.jcou.2017.08.020.

62. Jones, C.R.; Radford, R.L.; Armstrong, K.; Styring, P. What a waste! Assessing public perceptions of Carbon Dioxide Utilisation technology. Journal of CO2 Utilization 2014, 7, 51-54, https://doi.org/10.1016/j.jcou.2014.05.001.

63. Dutta, A.; Farooq, S.; Karimi, I.A.; Khan, S.A. Assessing the potential of CO2 utilization with an integrated framework for producing power and chemicals. Journal of CO2 Utilization 2017, 19, 49-57, https://doi.org/10.1016/j.jcou.2017.03.005.

64. Li, H.; Liang, J.; Li, H.; Zheng, X.; Tao, Y.; Huang, Z.-H.; Yang, Q.-H. Activated carbon fibers with manganese dioxide coating for flexible fiber supercapacitors with high capacitive performance. Journal of Energy Chemistry 2019, 31, 95-100, https://doi.org/10.1016/j.jechem.2018.05.008.

65. Hu, J.; Guo, Z.; Chu, W.; Li, L.; Lin, T. Carbon dioxide catalytic conversion to nano carbon material on the iron-nickel catalysts using CVD-IP method. Journal of Energy

Chemistry 2015, 24, 620-625, https://doi.org/10.1016/j.jechem.2015.09.006.

66. Islam, S.; Alfaruqi, M.H.; Song, J.; Kim, S.; Pham, D.T.; Jo, J.; Kim, S.; Mathew, V.; Baboo, J.P.; Xiu, Z.; Kim, J. Carbon-coated manganese dioxide nanoparticles and their enhanced electrochemical properties for zinc-ion battery applications. Journal of Energy Chemistry 2017, 26, 815-819, https://doi.org/10.1016/j.jechem.2017.04.002.

67. Zhang, L.; Li, L.; Zhang, Y.; Zhao, Y.; Li, J. Nickel catalysts supported on MgO with different specific surface area for carbon dioxide reforming of methane. Journal of Energy Chemistry 2014, 23, 66-72, https://doi.org/10.1016/S2095-4956(14)60119-4.

68. Zhang, L.; Wang, X.; Shang, X.; Tan, M.; Ding, W.; Lu, X. Carbon dioxide reforming of methane over mesoporous nickel aluminate/ $\gamma$-alumina composites. Journal of Energy Chemistry 2017, 26, 93-100, https://doi.org/10.1016/j.jechem.2016.08.001.

69. Nayak R.; Nanda B. A review on formulation, design of nanostructured material through oil-in-water microemulsion. Letters in Applied NanoBioScience https://doi.org/10.33263/LIANBS92.945951

70. Punvichai T.; Pioch D. Co-valorization of agro-industry by-products: effect of citrus oil on the quality of soap derived from palm fatty acid distillate and spent bleaching cla. Letters in Applied NanoBioScience 2019, 8, 571-575, https://doi.org/10.33263/LIANBS83.571575. 